\title{
The development of rat Leydig cell progenitors in vitro: how essential is luteinising hormone?
}

\author{
Katja J Teerds ${ }^{1,2}$, Eddy Rijntjes ${ }^{2}$, Margarita B Veldhuizen-Tsoerkan ${ }^{1}$, Focko F G Rommerts ${ }^{3}$ \\ and Mieke de Boer-Brouwer ${ }^{1}$ \\ ${ }^{1}$ Department of Biochemistry and Cell Biology, Faculty of Veterinary Medicine, Utrecht University, Utrecht, The Netherlands \\ ${ }^{2}$ Human and Animal Physiology Group, Department of Animal Sciences, Wageningen University, Marijkeweg 40, 6709 PG Wageningen, The Netherlands \\ ${ }^{3}$ Department of Internal Medicine, Erasmus Medical Centre, Erasmus University, Rotterdam, The Netherlands \\ (Correspondence should be addressed to K J Teerds; Email: katja.teerds@wur.nl)
}

\begin{abstract}
Luteinising hormone (LH) appears to be important for the establishment of the adult-type Leydig cell population. The role of LH in the initial steps of stem Leydig cell/precursor cell differentiation is less clear. The aim of the present study was to elucidate the role of LH in the differentiation of spindle-shaped mesenchymal-like cells into Leydig cell progenitors. Interstitial cells were isolated from rat testes at three different ages reflecting different phases in development, and cultured in the presence of increasing concentrations of LH (ranging from 0.01 to $10 \mathrm{ng} / \mathrm{ml}$ ). Cells were isolated from 10-day-old rats when stem Leydig cells/precursor cells are abundant; 13-day-old rats when the first $3 \beta$-hydroxysteroid dehydrogenase ( $3 \beta$-HSD)-positive Leydig cell progenitors have developed in the strain of rats used in this study; and 18-day-old rats just prior to the wave of progenitor proliferation. Immunohistochemistry revealed that before stem Leydig cells differentiate into progenitor cells, they acquire functional $\mathrm{LH}$ receptors and become precursor cells.
\end{abstract}

This was confirmed by an in vivo immunohistochemical doublelabelling experiment. Addition of $\mathrm{LH}$ to the cultures increased the percentage of LH/3 $\beta$-HSD-labelled Leydig cell progenitors, while the percentage of cells solely expressing the LH receptor decreased. Cell proliferation was negligible, suggesting that the increase in $3 \beta$-HSD-positive cells is the result of precursor cell differentiation. When interstitial cells were isolated from 13-day-old rats and to a lesser extent from 10-dayold rats, a small proportion of the precursors could develop into progenitor cells independent of the presence of $\mathrm{LH}$. In conclusion: before Leydig stem cells differentiate into $3 \beta$ HSD-positive progenitor cells, they acquire LH receptors and become precursor cells. LH appears to be essential, even at very low doses for the differentiation of these precursor cells into $3 \beta$ HSD-positive progenitors, although a subpopulation of precursor cells can develop into progenitors independently of LH. Journal of Endocrinology (2007) 194, 579-593

\section{Introduction}

The main function of Leydig cells in the prepubertal and adult testis is the production of androgens, essential for the progression of spermatogenesis. Synthesis and secretion of androgens by Leydig cells is stimulated by the gonadotrophin luteinising hormone (LH; Ahmad et al. 1973, Sharpe 1987). Testicular secretion of androgens depends not only on the activity of the interstitial Leydig cells, but also on the number of these cells present in the testis.

In rats, two defined periods of proliferation and differentiation can be discerned before the final population of Leydig cells in the adult testis is established. The first wave occurs during foetal life and results in a foetal population of Leydig cells. The second wave takes place during the prepubertal period and gives rise to the adult population of Leydig cells (Mendis-Handagama et al. 1987, Hardy et al. 1989). After birth, the number of foetaltype Leydig cells undergoes some decrease; $50-75 \%$ of the original foetal-type Leydig cell population present at birth persists in the adult testis (Kerr \& Knell 1988). The second generation of Leydig cells, the so-called adult-type Leydig cells, develops from stem Leydig cells through several steps of differentiation and proliferation during (pre)puberty (Lording \& de Kretser 1972, Hardy et al. 1989, De Kretser \& Kerr 1994, Mendis-Handagama \& Ariyaratne 2001, Haider 2004, Ge et al. 2006). Spindle-shaped stem Leydig cells of mesenchymal origin, identified by the presence of platelet-derived growth factor (PDGF) receptor- $\alpha$, leukaemia-inhibiting factor (LIF) receptor and c-kit, and the absence of $\mathrm{LH}$ receptors and steroidogenic enzyme expression, are thought to differentiate into $3 \beta$ hydroxysteroid dehydrogenase ( $3 \beta$-HSD)-positive Leydig cell progenitors between days 10 and 13 after birth. Subsequently, these cells undergo further proliferation and differentiate in immature adult-type Leydig cells between days 28 and 35 after birth. By that time, the proliferative activity of these cells is decreasing rapidly and the immature Leydig cells develop into mature terminally differentiated adult-type Leydig cells. By the end of puberty, the development of the adult population is 
completed. Each step in this differentiation process is characterised by specific morphological aspects of the developing cells (Vergouwen et al. 1991, Mendis-Handagama \& Ariyaratne 2001, Haider 2004) and the expression of specific steroidogenic enzymes, such as $3 \beta-\mathrm{HSD}, 5 \alpha$-reductase, cholesterol side chain cleavage $\left(\mathrm{P} 450_{\mathrm{scc}}\right)$ and $17 \alpha$-hydroxylase (P450 $17 \alpha$; Wiebe 1976, O'Shaughnessy et al. 2000, 2002, Ge et al. 2005).

A considerable number of studies have been performed to investigate the regulation of this complicated developmental process in more detail (Ketelslegers et al. 1978, Chemes et al. 1985, Teerds et al. 1989, Hardy et al. 1990). Treatment of hypophysectomised prepubertal rats with highly purified LH has been shown to stimulate both differentiation of stem Leydig cells/precursor cells and proliferation of the newly formed progenitor Leydig cells (Teerds et al. 1989). Similarly, treatment of prepubertal boys with the LH analogue human chorionic gonadotrophin (hCG) induced the formation of new Leydig cells through stem cell/precursor cell differentiation (Chemes et al. 1985).

Recently, more information has become available about the identity of the stem Leydig cell/precursor cell and the endocrine/paracrine regulation of Leydig cell development, although these studies are sometimes contradictory. One of the first investigations on Leydig cell differentiation in vitro showed that the addition of $\mathrm{LH}$ alone did not result in the formation of progenitor cells from mesenchymal-like stem cells/precursor cells. In addition to $\mathrm{LH}$, the androgen dihydrotestosterone (DHT) was required for the transition of these cells into Leydig cell progenitors (Hardy et al. 1990, 1991). The specific requirement of DHT is intriguing because endogenous androgens are continuously produced by LH-stimulated foetal-type and progenitor Leydig cells. Moreover, the in vitro added DHT is thought to be rapidly metabolised and can thus exert its effect for only a brief period of time (Hardy et al. 1990). In knockout studies, the role of $\mathrm{LH}$ in the initial phases of Leydig cell development was further questioned. In the absence of the Desert hedgehog (Dhh) gene (Clark et al. 2000) or PDGF-A (Gnessi et al. 2000), Leydig cell progenitor formation did not occur, despite plasma LH levels being normal. When gonadotrophin levels were very low or below the detection limit of the RIA used, such as in hypogonadal (hpg) mice (Baker \& O'Shaughnessy 2001) or in case of disruption of LH signalling in LH receptor knockout mice (Zhang et al. 2001), adult-type Leydig cell development appeared to be severely affected though possibly not completely inhibited. Moreover, Ariyaratne et al. (2000) observed, using immunohistochemical techniques, that in progenitor cells the steroidogenic enzymes $3 \beta$-HSD, $\mathrm{P} 450_{\text {scc }}$ and $\mathrm{P} 450_{17 \alpha}$ appeared before $\mathrm{LH}$ receptors could be detected. The latter study suggested that, like in foetal-type Leydig cells (Majdic et al. 1998), the development of the steroidogenic capacity of the Leydig cell progenitors precedes their responsiveness to LH.

In the present study, a different approach was used to obtain more information concerning the factors involved in the formation of Leydig cell progenitors. We hypothesise that spindle-shaped Leydig stem cells (Ge et al. 2006) first develop into LH receptor expressing cells (which will be named spindle-shaped precursor cells to discriminate them from stem Leydig cells that do not express LH receptors) before they differentiate into $\mathrm{LH}$ receptor and $3 \beta-\mathrm{HSD}$-positive progenitor cells. The emphasis in this study is on the role of LH in the conversion of $\mathrm{LH}$ receptor-positive precursor cells into progenitor cells. In order to investigate this, we have isolated interstitial cells from rat testes at three different ages reflecting different phases in this developmental process: from 10-dayold rats when in the substrain of Wistar rats used in the present study, foetal-type Leydig cells and Leydig stem cells/precursor cells are present but Leydig cell progenitors have not yet developed; from 13-day-old rats when in the substrain of Wistar rats used in this study, the first Leydig cell progenitors have been formed; and from 18-day-old rats just prior to the wave of proliferation of the progenitor cells (Hardy et al. 1989). Spindle-shaped precursor cells and progenitor Leydig cells were identified by the presence of $3 \beta-H S D$ activity and/ or $\mathrm{LH}$ receptors. LH-stimulated cAMP production was measured as a functional index of the $\mathrm{LH}$ receptors.

\section{Materials and Methods}

\section{Isolation of cells}

Immature Wistar rats were obtained from the Central Animal Facilities of Utrecht University (Utrecht, the Netherlands). For each experiment, groups of 25-30 animals were killed 10, 13 or 18 days after birth by $\mathrm{CO}_{2}$ asphyxiation and decapitation. Testes were removed and put in HBSS (Gibco, Life Technologies). Subsequently, testes were decapsulated and subjected to enzymatic digestion at $37^{\circ} \mathrm{C}$ in a shaking water bath ( 80 cycles $/ \mathrm{min})$, using $5 \mathrm{mg}$ collagenase (type IV, $213 \mathrm{U} / \mathrm{mg}$; Worthington Biochemical Corp., Freehold, NJ, USA) in $20 \mathrm{ml}$, Hanks buffered salt solution (HBSS). After $12.5 \mathrm{~min}$, the tube was removed from the water bath and HBSS was added until a total volume of $50 \mathrm{ml}$ was reached. The larger tubular fragments were allowed to settle under unit gravity for $10 \mathrm{~min}$. The supernatant was removed and again fragments and cell clumps in this supernatant were allowed to settle for $10 \mathrm{~min}$. From this tube, the supernatant was collected, filtered through a $60 \mathrm{~m}$ gauze and centrifuged for $2.5 \mathrm{~min}$ at $200 \mathrm{~g}$. After centrifugation, the supernatant was removed and the pellet was resuspended in $2 \mathrm{ml}$ culture medium consisting of RPMI 1640 supplemented with penicillin $(100 \mathrm{U} / \mathrm{ml})$, streptomycin $(100 \mathrm{~g} / \mathrm{ml}), 0 \cdot 1 \%$ bovine serum albumin (BSA) and glutamine ( $2 \mathrm{mM}$; all substances were obtained from Gibco). The supernatant collected after centrifugation was centrifuged again for $2.5 \mathrm{~min}$ at $200 \mathrm{~g}$ and this pellet was also resuspended in $2 \mathrm{ml}$ culture medium. Both cell suspensions were put together. Cells were seeded either in 24-well plates on glass coverslips at a density of 150000 cells 
per well or in 96-well plates at a density of 75000 cells per well. The cell isolates consisted of myoid cells, fibroblasts, macrophages, spindle-shaped mesenchymal-like cells, Sertoli cells, foetal-type Leydig cells and, depending on the age of the rat at the time of cell isolation, Leydig cell progenitors. The spindle-shaped mesenchymal-like cells, which in the testis can be found in a peritubular as well as a perivascular location (Haider 2004), are considered to be the stem cells/ precursor cells of the Leydig cell progenitors (Lording \& De Kretser 1972, Hardy et al. 1990, Teerds et al. 1999). The reason why we chose to use a relatively impure interstitial cell preparation was to include those cell types that have been shown in vivo to secrete paracrine factors known to influence the differentiation of stem Leydig cells, such as the Sertoli cell and peritubular/myoid cell-derived growth factors, PDGF-A, transforming growth factor- $\alpha$ (TGF- $\alpha$ )/ epidermal growth factor (EGF), stem cell factor (SCF) and LIF (Ge et al. 2006).

The cells were cultured in RPMI 1640 medium with additions, as indicated above, for either $3 \mathrm{~h}, 3,8$ or 15 days at $37^{\circ} \mathrm{C}$ in air plus $5 \% \mathrm{CO}_{2}$ in the presence of $0,0 \cdot 01,0 \cdot 1$ or $10 \mathrm{ng} / \mathrm{ml}$ ovine LH respectively (NIH-LH-S20, Endocrinology Study Section of the National Institute of Health, Bethesda, MD, USA). In some experiments, oestradiol (Sigma) or DHT (Sigma) were also added to the culture medium at a concentration of 0.5 and $26 \mathrm{M}$ respectively. The medium was replaced every 2 days except when the cells were cultured in the presence of DHT, in which case the medium was replaced daily.

The experiments described in the present study have been approved by the ethical committee for laboratory animal welfare of the Faculty of Veterinary Medicine, Utrecht University, Utrecht, the Netherlands.

\section{cAMP production}

Hormone responsiveness of the isolated cells was measured by the production of cAMP in the culture medium. Interstitial cells isolated from 13-day-old rat testes were cultured in 24-well plates for 3,8 or 15 days in the presence of $0,0 \cdot 1$ or $10 \mathrm{ng} / \mathrm{ml} \mathrm{LH}(\mathrm{NIH})$. At the end of the culture period, medium was removed and replaced by fresh medium. Cells were cultured for another $2 \mathrm{~h}$ in the presence of $0.1 \% \mathrm{BSA}$, 0.1 mM 3-isobutyl-1- methylxanthine (IBMX; Sigma) and 0 or $100 \mathrm{ng} / \mathrm{ml} \mathrm{LH} \mathrm{(NIH)} \mathrm{after} \mathrm{which} \mathrm{the} \mathrm{medium} \mathrm{was}$ collected for measurement of cAMP production. Precursor cell development into progenitors was checked in these cultures using $3 \beta-\mathrm{HSD}$ enzyme histochemistry.

cAMP was assayed according to the method described by Harper \& Brooker (1975) with minor modifications as reported by Schipper et al. (1996). The cAMP antibody used in the assay was a gift from Dr Stoof (Free University, Amsterdam, The Netherlands). The assay was validated for the use of culture medium and corrected for the presence of serum in the media samples. All samples were assayed in duplicate. The sensitivity of the assay was $0 \cdot 125 \mathrm{pmol} / \mathrm{ml}$ and the inter- and intra-assay coefficients of variation were 2 and $8 \%$ respectively.

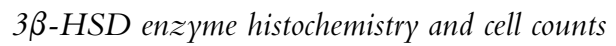

Interstitial cells isolated from 10-, 13- or 18-day-old rats were cultured on glass coverslips in the presence of $0,0 \cdot 01,0 \cdot 1$ or $10 \mathrm{ng} / \mathrm{ml} \mathrm{LH}(\mathrm{NIH})$ in 24-well plates. After $3 \mathrm{~h}, 3$ or 8 days of culture, $3 \beta$-HSD activity was determined in the cultures according to the method of Lojda et al. (1979) with minor modifications as described by Molenaaret al. (1986a). On each coverslip a total of at least 1000 cells was counted (3 $\beta$-HSDpositive plus -negative cells), using a Nikon Optiphot 2 microscope, equipped with differential interference contrast optics. The number of blue-stained 3 $\beta-H S D$-positive cells was expressed as percentage of the total number of cells counted per coverslip. In control experiments in which the enzyme substrate $5 \alpha$-androstane-3 $\beta$-ol-17-one was left out, no blue staining was observed.

\section{Cell density assay}

In order to investigate the viability of the cells in the cultures, methylene blue uptake by the cells was measured, using a colorimetric assay (Goldman \& Bar-Shavit 1979). Briefly, interstitial cells isolated from 10-, 13- or 18-day-old rats were cultured in 96-well plates for $3 \mathrm{~h}, 3$ or 8 days in the presence of $0,0 \cdot 01,0 \cdot 1$ or $10 \mathrm{ng} / \mathrm{ml} \mathrm{LH}(\mathrm{NIH})$ followed by fixation in $2.5 \%$ buffered formaldehyde. The cells were washed twice in $10 \mathrm{mM}$ borate buffer (pH 8.5), stained with $1 \%$ methylene blue in borate buffer for $10 \mathrm{~min}$ at $24{ }^{\circ} \mathrm{C}$ and then rinsed with borate buffer. Specific cell-incorporated methylene blue was dissolved in $0.1 \mathrm{M} \mathrm{HCl}\left(60 \mathrm{~min}, 37^{\circ} \mathrm{C}\right)$ and determined by reading the absorbance at $595 \mathrm{~nm}$ using a photospectrometer. The uptake of methylene blue was linearly correlated with the number of viable cells (Goldman \& Bar-Shavit 1979).

\section{Scintillation counting}

The proliferative capacity of the interstitial cell preparations was determined by culturing cells isolated from 13-day-old rat testes in 96-well plates (75 000 cells/well) in the presence of 0 or $10 \mathrm{ng} / \mathrm{ml} \mathrm{LH}$ for 1,3 or 8 days. During the last $18 \mathrm{~h}$ of the culture period, $\left[{ }^{3} \mathrm{H}\right]$ thymidine $(2 \mu \mathrm{Ci} / \mathrm{ml} ; \quad \mathrm{SA}$, $0.5 \mathrm{Ci} / \mathrm{mmol}$; Amersham), a marker for cell proliferation which is incorporated in cells in the S-phase of the cell cycle, was added to the cultures. Cells were harvested onto glass fibre filters and the amount of incorporated radioactivity was determined using a liquid scintillation analyser (Beta plate, LKB, Turku, Finland).

\section{In situ hybridisation}

Interstitial cells isolated from 13-day-old rats were cultured on coverslips for 8 days in the presence of 0 or $10 \mathrm{ng} / \mathrm{ml} \mathrm{LH}$ (NIH), fixed in buffered formalin for $15 \mathrm{~min}$ and washed with 
PBS. The DIG RNA labelling kit (Boehringer, Mannheim, Germany) was used for the detection of $3 \beta$-HSD mRNA in these cells, according to the manufactures protocol with minor modifications. In brief, endogenous alkaline phosphatase activity was blocked by treatment with $0.2 \mathrm{M} \mathrm{HCl}$ and $0 \cdot 3 \%$ Triton X-100 in PBS, followed by pre-incubation in proteinase $\mathrm{K}$ buffer for $30 \mathrm{~min}$ at $37^{\circ} \mathrm{C}$. Cells were then incubated in $10 \mathrm{~g} / \mathrm{ml}$ proteinase $\mathrm{K}$ in the same buffer at $37^{\circ} \mathrm{C}$ for $30 \mathrm{~min}$. The reaction was stopped by transfer of the coverslips to a $0 \cdot 2 \%$ ice-cold glycine solution for $1 \mathrm{~min}$. Next, the coverslips were covered with $200 \mu \mathrm{l}$ pre-hybridisation solution $(5 \times$ SSC, $5 \times$ Denhardt's solution, $50 \%$ deionised formamide, $250 \mu \mathrm{g} / \mathrm{ml}$ yeast t-RNA, $250 \mu \mathrm{g}$ denatured salmon sperm DNA, $4 \mathrm{mM}$ EDTA) and incubated for at least $3 \mathrm{~h}$ at $50{ }^{\circ} \mathrm{C}$. The coverslips were rinsed in alcohol, dried and covered with hybridisation solution, consisting of the pre-hybridisation solution (without salmon sperm DNA) to which $10 \mathrm{ng}$ digoxygenin-labelled $3 \beta$-HSD cRNA probe (gift from Dr Mason, University of Edinburgh, Edinburgh, Scotland) per $20 \mu \mathrm{l}$ of hybridisation solution was added. Hybridisation proceeded overnight at $52{ }^{\circ} \mathrm{C}$ in a humified chamber.

The hybridisation probe was detected by an alkaline phosphatase-coupled anti-digoxygenin antibody according to the manufacturer's instructions (Boehringer) with minor modifications. Briefly, the coverslips were rinsed in buffer A $(0 \cdot 1 \mathrm{M}$ Tris- $\mathrm{HCl} \mathrm{pH} 7 \cdot 9,0 \cdot 15 \mathrm{M} \mathrm{NaCl})$, blocked by incubation with $0.5 \%$ blocking reagent (Boehringer) in buffer $\mathrm{A}$ and rinsed again with buffer $\mathrm{A}$. Next, the coverslips were incubated with an alkaline phosphatase conjugated antidigoxygenin antibody (Boehringer) diluted 1:5000 in buffer $A$, rinsed twice in buffer $A$ and equilibrated in buffer $B(0 \cdot 1 \mathrm{M}$ Tris- $\mathrm{HCl} \mathrm{pH} 9 \cdot 5,0 \cdot 1 \mathrm{M} \mathrm{NaCl}, 0.05 \mathrm{M} \mathrm{MgCl}_{2}$ ) before applying the colour detection substrate solution $(175 \mathrm{~g} / \mathrm{ml}$ 5-bromo-4-chloro-3-indolyl-phosphate (Boehringer) and $337.5 \mathrm{~g} / \mathrm{ml}$ nitroblue tetrazolium (NBT; Boehringer)) to buffer B. The coverslips were incubated overnight in the dark and the reaction was stopped by rinsing the coverslips in Tris$\mathrm{HCl}(0 \cdot 1 \mathrm{M}, \mathrm{pH} 8 \cdot 1)$ EDTA $(1 \mathrm{mM})$ buffer after which the slips were mounted with fluoromount and stored at $4{ }^{\circ} \mathrm{C}$ in the darkness until further analysis.

\section{Immunohistochemistry}

$\mathrm{LH}$ receptor and $3 \boldsymbol{\beta}-\mathrm{HSD}$ double labelling in vitro Interstitial cells isolated from 13-day-old rats were cultured on glass coverslips in the presence of 0 or $10 \mathrm{ng} / \mathrm{ml} \mathrm{LH}(\mathrm{NIH})$ for 1,3 or 8 days, followed by fixation in $4 \%$ buffered formaldehyde. The cells were washed in 0.01 M PBS $(\mathrm{pH}$ 7.4), incubated with $0 \cdot 1 \mathrm{M}$ glycine in PBS for $30 \mathrm{~min}$ and rinsed again in PBS. Cells were permeablised by treatment with $0 \cdot 1 \%$ Triton X-100 in PBS for 5 min after which the coverslips were rinsed thoroughly with PBS. The cells were blocked with 10\% normal goat serum in PBS for $30 \mathrm{~min}$ and then incubated overnight at $4{ }^{\circ} \mathrm{C}$ with a combination of the two first antibodies: the polyclonal $3 \beta$-HSD antibody (a gift from Dr Payne, Stanford, CA, USA; diluted 1:100) and the monoclonal $\mathrm{LH}$ receptor antibody (P1B4, gift from $\mathrm{Dr}$ Wimalasema, University of Tennessee, Knoxville, TN, USA; diluted $1: 2000)$ in $0 \cdot 01 \mathrm{M}$ PBS to which $0 \cdot 05 \%$ BSA-c (Aurion, Wageningen, The Netherlands) was added. Cells were washed in PBS, followed by incubation for $1 \mathrm{~h}$ at room temperature with the second antibody mix: goat-anti-rabbit Alexa 568 (tetramethyl rhodamine isothiocyanate (TRITC), Molecular Probes Inc., Eugene, OR, USA) for the detection of $3 \beta-H S D$ and goat-anti-mouse Alexa 488 (fluorescein isothiocyanate (FITC), Molecular Probes Inc.) for the detection of the $\mathrm{LH}$ receptor. Both antibodies were diluted 1:100 in $0 \cdot 01 \mathrm{M}$ PBS to which $0 \cdot 05 \%$ BSA-c (Aurion) was added. To stop the incubation, the coverslips were rinsed several times in PBS, mounted with fluorsave and stored in the dark at $4{ }^{\circ} \mathrm{C}$ until microscopical examination. Fluorescent labelling for the presence of $3 \beta-\mathrm{HSD}$ and $\mathrm{LH}$ receptor was visualised using a Leica TCS MP confocal laser-scanning microscope (Leica, Heidelberg, Germany). The percentage of single- or double-labelled cells was determined by counting at least 200 fluorescent-labelled cells per culture. In control experiments, the first antibodies were replaced by normal rabbit serum (3 $\beta-\mathrm{HSD})$ and normal mouse serum (LH receptor). All controls showed a low level of irregular background labelling which could be easily distinguished from the specific labelling.

\section{LH receptor and $3 \beta-H S D$ double labelling in vivo}

Testicular tissue from 7-, 8-, 10-, 12- and 13-day-old rats was collected, fixed in methacarn (60\% methanol, 30\% chloroform and $10 \%$ acetic acid) for $4 \mathrm{~h}$ at room temperature, dehydrated and embedded in paraffin. Five micrometre thick sections were cut and processed for immunohistochemistry as described previously (Teerds \& Dorrington 1993, Teerds et al. 1999). Briefly, the sections were deparaffinised and endogenous peroxidase activity was blocked with $1 \% \mathrm{H}_{2} \mathrm{O}_{2}$ in methanol. Slides were subsequently rinsed in PBS and incubated with $0 \cdot 1 \mathrm{M}$ glycine in PBS, blocked with $10 \%$ normal goat serum in PBS and incubated overnight at $4{ }^{\circ} \mathrm{C}$ with a combination of the two first antibodies $3 \beta$-HSD (diluted 1:300 in PBS/BSA-c) and $\mathrm{LH}$ receptor (diluted 1:1000 in PBS/BSA-c). Slides were rinsed and incubated with both secondary antibodies, a biotinylated horse-antimouse antibody and an alkaline phosphatase-labelled goatanti-rabbit antibody (Vector Laboratories, diluted 1:200 in PBS/BSA-c) for $1 \mathrm{~h}$. Sections were washed in PBS and incubated with the components avidin and biotin of the $\mathrm{ABC}$ staining kit elite (Vector Laboratories) for $1 \mathrm{~h}$ at a dilution of 1:1000 (in PBS/BSA-c). Slides were rinsed again and bound $\mathrm{LH}$ receptor antibody was visualised with $0.6 \mathrm{mg} / \mathrm{ml} \mathrm{3,3^{ \prime } -}$ diaminobenzidine tetrachloride (DAB, Sigma) dissolved in PBS to which $0 \cdot 03 \% \mathrm{H}_{2} \mathrm{O}_{2}$ was added (brown staining). Slides were rinsed in PBS and bound 3 $\beta$-HSD antibody was visualised by incubating the slides with a solution containing $1 \mathrm{mg}$ naphthol AS MX phosphate dissolved in $50 \mu \mathrm{l} \mathrm{N}, \mathrm{N}-$ dimethylformamide, $8 \mathrm{ml}$ Tris- $\mathrm{HCl}(0 \cdot 1 \mathrm{M}, \mathrm{pH} 8 \cdot 5), 2 \mathrm{mg}$ 
fast blue base dissolved in $50 \mu \mathrm{l}$ of $2 \mathrm{~N} \mathrm{HCl}$ and $50 \mu \mathrm{l} 4 \%$ $\mathrm{NaNO}_{2}$ (all chemicals obtained from Sigma) for $\sim 15 \mathrm{~min}$ at $37^{\circ} \mathrm{C}$ to demonstrate the presence of alkaline phosphatase (blue staining). The slides were rinsed and mounted; the sections were not counterstained. In control experiments, the primary antibodies were replaced by normal rabbit and mouse serum. Non-specific staining was not observed in these control sections.

BrdU and 3 $\beta$-HSD double labelling in vitro Interstitial cells were isolated form 13-day-old rat testes, plated on glass coverslips and cultured for 1 or 3 days in the presence of 0 or $10 \mathrm{ng} / \mathrm{ml} \mathrm{LH}(\mathrm{NIH})$. Three hours before termination of the experiment, bromodeoxyuridine (BrdU; $3 \cdot 3 \mu \mathrm{g} / \mathrm{ml}$, Sigma) was added to the cultures. Cells were fixed in methacarn for $10 \mathrm{~min}$ and then stored at $4{ }^{\circ} \mathrm{C}$ in $70 \%$ alcohol until further processing. BrdU is incorporated in the DNA of cells in the S-phase of the cell cycle and thus a maker for the proliferative activity of the cells. Immunohistochemical labelling was carried out as described before (Slegtenhorst-Eegdeman et al. 1998) with minor modifications. Briefly, the cells were pretreated with periodic acid prior to incubation with a monoclonal antibody (MAB) against BrdU (diluted 1:100, Becton Dickinson Immunocytometry Systems, San Jose, CA, USA) for $2 \mathrm{~h}$ at room temperature, rinsed and incubated with a peroxidase-conjugated rabbit-anti-mouse antibody (diluted 1:100, Sigma). Labelling was visualised using DAB (Sigma) enhanced by nickel. After this incubation, the cells were extensively rinsed with PBS and incubated overnight at $4{ }^{\circ} \mathrm{C}$ with the polyclonal antibody against $3 \beta-\mathrm{HSD}$ as described above. Labelling was visualised using DAB (Sigma). In the control experiment, the $3 \beta-H S D$ antibody was replaced by normal rabbit serum. Double-labelled cells were recognised by a dark brown to black nucleus (BrdU) and brownish stained cytoplasm (3ß-HSD). Single-labelled cells had either a brown to black nucleus or brownish stained cytoplasm.

\section{Statistical analysis}

To test for significant differences in multi-comparisons, ANOVA was used, followed by Bonferroni's post hoc test if equal variances could be assumed or Dunnett's post hoc test to correct for unequal variances. Differences were considered to be significant when $P<0 \cdot 05$. In general, the experiments were performed in triplicate or quadruplicate and repeated at least thrice using different cell preparations. All data are expressed as mean \pm s.D.

\section{Results}

\section{Hormone responsiveness}

cAMP levels in the culture medium were measured to investigate whether LH receptors in Leydig cell progenitors and presumably their precursors could be activated under the present experimental conditions. Interstitial cells were isolated from testes of 13-day-old rats and cultured for 3, 8 or 15 days in the presence of $0,0 \cdot 1$ or $10 \mathrm{ng} / \mathrm{ml} \mathrm{LH}$. Under basal conditions, cells cultured without any additions or in the presence of $0 \cdot 1 \mathrm{ng} / \mathrm{ml} \mathrm{LH}$ produced comparable low amounts of cAMP, while cells that had been cultured in the presence of $10 \mathrm{ng} / \mathrm{ml} \mathrm{LH}$, produced two- to tenfold higher levels of cAMP when compared with control cells (Fig. 1A). When cells were stimulated with $100 \mathrm{ng} / \mathrm{ml} \mathrm{LH}$ during the last $2 \mathrm{~h}$ of the incubation period, cAMP production was increased more than 100-fold (Fig. 1B) compared with under basal conditions (Fig. 1A). The capacity for maximal cAMP production was somewhat diminished in cells that had been cultured continuously in the presence of $10 \mathrm{ng} / \mathrm{ml}$. From these results, it can be concluded that cultured Leydig cell progenitors and presumably their precursors remain
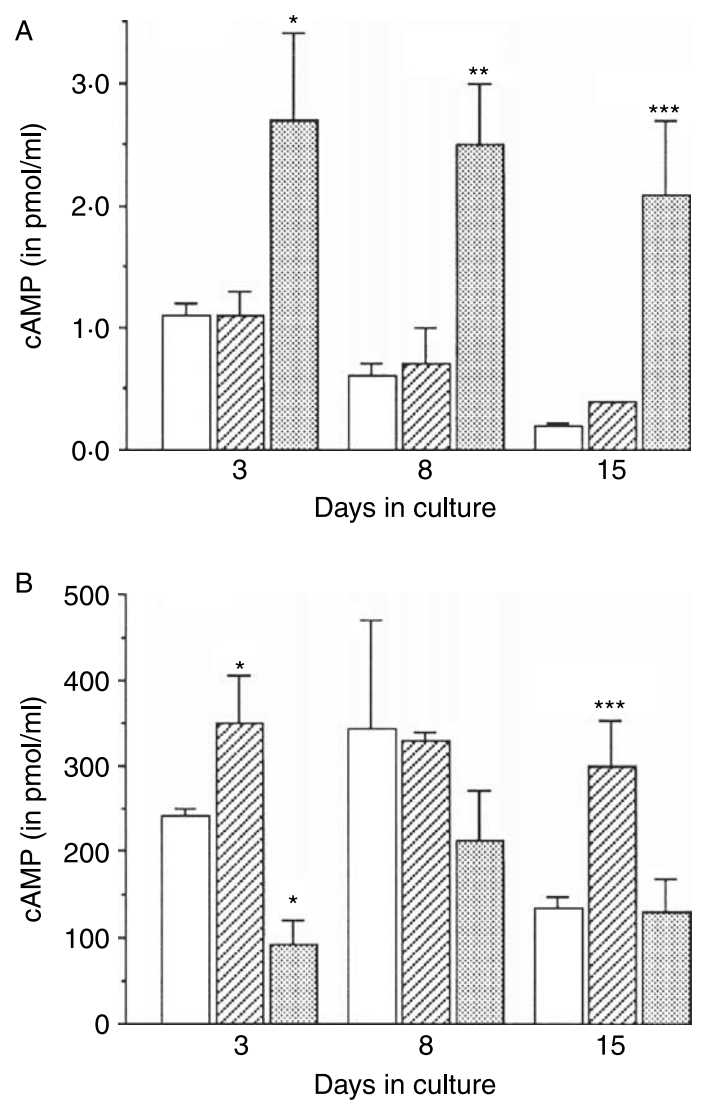

Figure $1 \mathrm{LH}$-induced cAMP production in interstitial cells. Cells were isolated from 13-day-old rat testes and cultured for 3, 8 or 15 days in the presence of 0 (open bars), $0 \cdot 1 \mathrm{ng} / \mathrm{ml}$ (hatched bars) or $10 \mathrm{ng} / \mathrm{ml}$ (stippled bars) LH. At the end of the culture period, cells were incubated for $2 \mathrm{~h}$ either in fresh medium with $0 \cdot 1 \mathrm{M} \mathrm{IBMX}(\mathrm{A})$ or in order to measure stimulated cAMP production in the presence of $100 \mathrm{ng} / \mathrm{ml} \mathrm{LH}$ and $0 \cdot 1 \mathrm{M} \mathrm{IBMX}(\mathrm{B})$. CAMP levels in the culture medium are expressed as $\mathrm{pmol} / \mathrm{ml}$ culture medium. Values are presented as mean \pm s.D. When no bar is present, the s.D. is too small to become visualized. *Significantly different from day 3 control cultures; ${ }^{* *}$ significantly different from day 8 control cultures; ***significantly different from day 15 control cultures, $P<0 \cdot 05$. 
responsive towards $\mathrm{LH}$ in terms of cAMP production under the present experimental conditions.

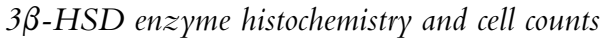

The percentage of $3 \beta$-HSD-positive cells was measured as an index of development of precursor cells into Leydig cell progenitors. The percentage of $3 \beta$-HSD-positive cells was $<$ $2 \%$ in freshly isolated interstitial cell preparations from $10-$ to 13-day-old rats (Figs 2A, B and 3A, C) and 10-12\% in cell preparations from 18-day-old animals (Figs 2C and 3E). The $3 \beta$-HSD-positive cells present $3 \mathrm{~h}$ after isolation in the cultures from 10-day-old testes are foetal-type Leydig cells; in the cultures with cells isolated from 13-day-old rats, the $3 \beta$ HSD-positive cells consisted of a mix of foetal-type Leydig cells and some newly developed Leydig cell progenitors though the number of progenitors will be limited. In the freshly isolated cell preparations from 18-day-old rat testes, the population of $3 \beta$-HSD-positive cells largely consisted of Leydig cell progenitors, since at this age, the progenitor Leydig cells will have outnumbered the foetal-type cells (Kerr \& Knell 1988, Ariyaratne et al. 2000). We did not undertake any effort to discriminate foetal-type Leydig cells and progenitor cells from each other in the cultures due to the absence of appropriate markers that can discriminate 100\% successfully between these two cell types.

Interstitial cells isolated from 10-day-old rats showed a twofold increase in the percentage of $3 \beta$-HSD-positive cells after being cultured in the presence of $0 \cdot 1$ or $10 \mathrm{ng} / \mathrm{ml} \mathrm{LH}$ for 3 days (Fig. 2A). After 8 days of culture, the percentage of $3 \beta$ HSD-positive cells had increased fourfold. Although the percentage of $3 \beta$-HSD-positive cells did not increase significantly when cells were cultured without LH, some autonomous progenitor formation did seem to take place (Figs $2 \mathrm{~A}$ and $3 \mathrm{~B}$ ). In a few cases, interstitial cells were isolated from testes of 8 -day-old rats. In these experiments, the percentage of $3 \beta$-HSD-positive cells that had developed after 8 days of culture in the presence of LH was slightly lower, though not significantly different from the percentage of progenitor cells formed when cells were isolated from 10-dayold rat testes (data not shown). When interstitial cells were isolated from 13-day-old rats, a fourfold increase in the percentage of $3 \beta$-HSD-positive progenitor cells was observed after 3 days of culture without LH, suggesting that these cells underwent spontaneous autonomous differentiation (Fig. 2B). Addition of LH further augmented this differentiation process in a dose-dependent manner (Fig. 2B). After 8 days of culture in the presence of $\mathrm{LH}$, the percentage of $3 \beta$ HSD-positive cells had even further increased. In the absence of $\mathrm{LH}$, however, no further increase in the percentage of $3 \beta$ HSD-positive Leydig cell progenitors was observed after prolonged culture (Figs 2B and 3D). Interstitial cells isolated from 18-day-old rats did not show any spontaneous differentiation into $3 \beta$-HSD-positive Leydig cell progenitors. High doses of $\mathrm{LH}$ and prolonged culture periods were required for the stimulation of precursor cell differentiation
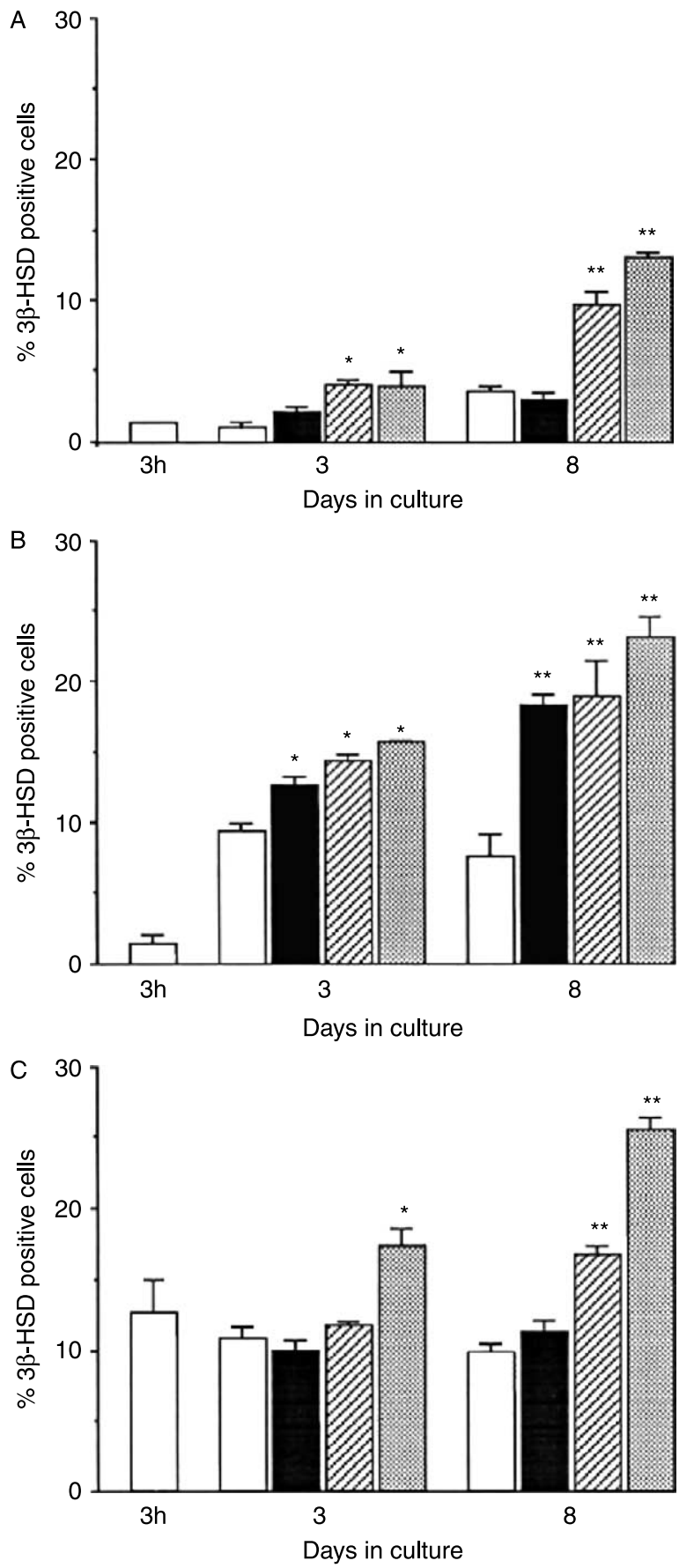

Figure 2 Differentiation of mesenchymal-like precursor cells into $3 \beta$ HSD-positive Leydig cell progenitors. Interstitial cells were isolated from (A) 10-, (B) 13- and (C) 18-day-old rat testes and cultured in the presence of 0 (open bars), $0 \cdot 01 \mathrm{ng} / \mathrm{ml}$ (filled bars), $0 \cdot 1 \mathrm{ng} / \mathrm{ml}$ (hatched bars) or $10 \mathrm{ng} / \mathrm{ml}$ (stippled bars) LH during $3 \mathrm{~h}, 3$ or 8 days. At the end of the culture period, the percentage of $3 \beta$-HSD-positive cells was determined. The results represent the means of quadruplicate cultures from one representative experiment; values are expressed as mean \pm S.D. When no bar is present, the S.D. is too small to become visualized. *Significantly different from day 3 control cultures; ** significantly different from day 8 control cultures, $P<0 \cdot 05$. 

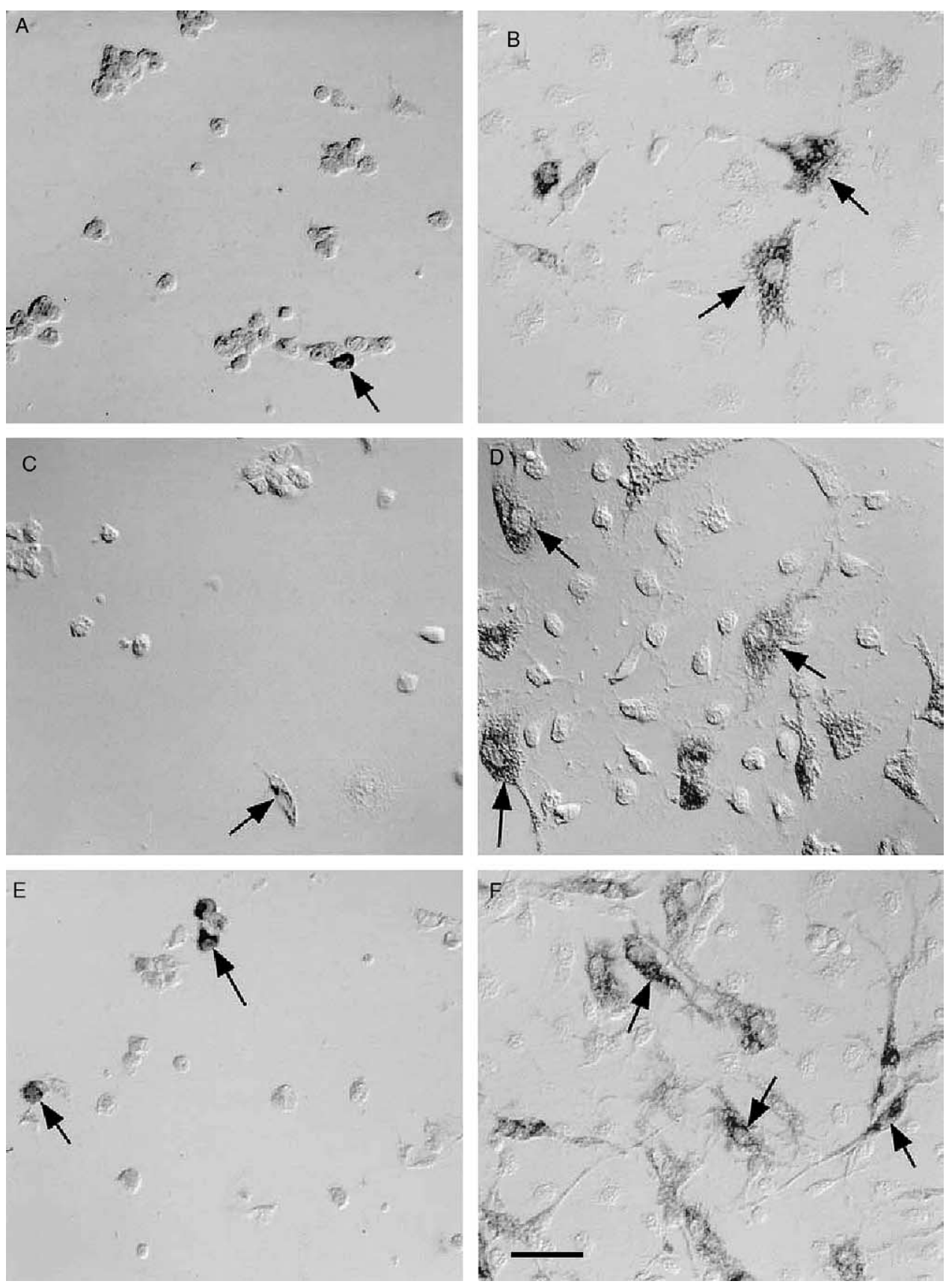

Figure $33 \beta-\mathrm{HSD}$ enzyme histochemistry: representative examples of cell cultures. Interstitial cells were isolated from ( $A$ and $B$ ) 10-, (C and D) 13- or (E and F) 18-day-old rat testes. Cells after 3 h of culture (A, $C$ and E) in the absence of $\mathrm{LH}$, or 8 days of culture (B, D and F) in the presence of $10 \mathrm{ng} / \mathrm{ml} \mathrm{LH}, 3 \beta-\mathrm{HSD}$-positive cells stained blue; some representative cells are indicated by arrows. Original magnification $574 \times$, bar $17 \mathrm{~m}$.

into $3 \beta$-HSD-positive cells (Figs 2C and 3F). It cannot be excluded that in this case after 8 days of culture in the presence of LH some progenitor cells may have already differentiated into immature Leydig cells.

Independent of the age of the animals at the time of interstitial cell isolation, the culture conditions of the cells or the length of the culture period, no significant changes in cell numbers between controls and LH-treated cells could be detected using the methylene blue cell viability assay (data not shown).

In order to investigate whether proliferation of cells in culture took place, $\left[{ }^{3} \mathrm{H}\right]$ thymidine or BrdU, both markers for 

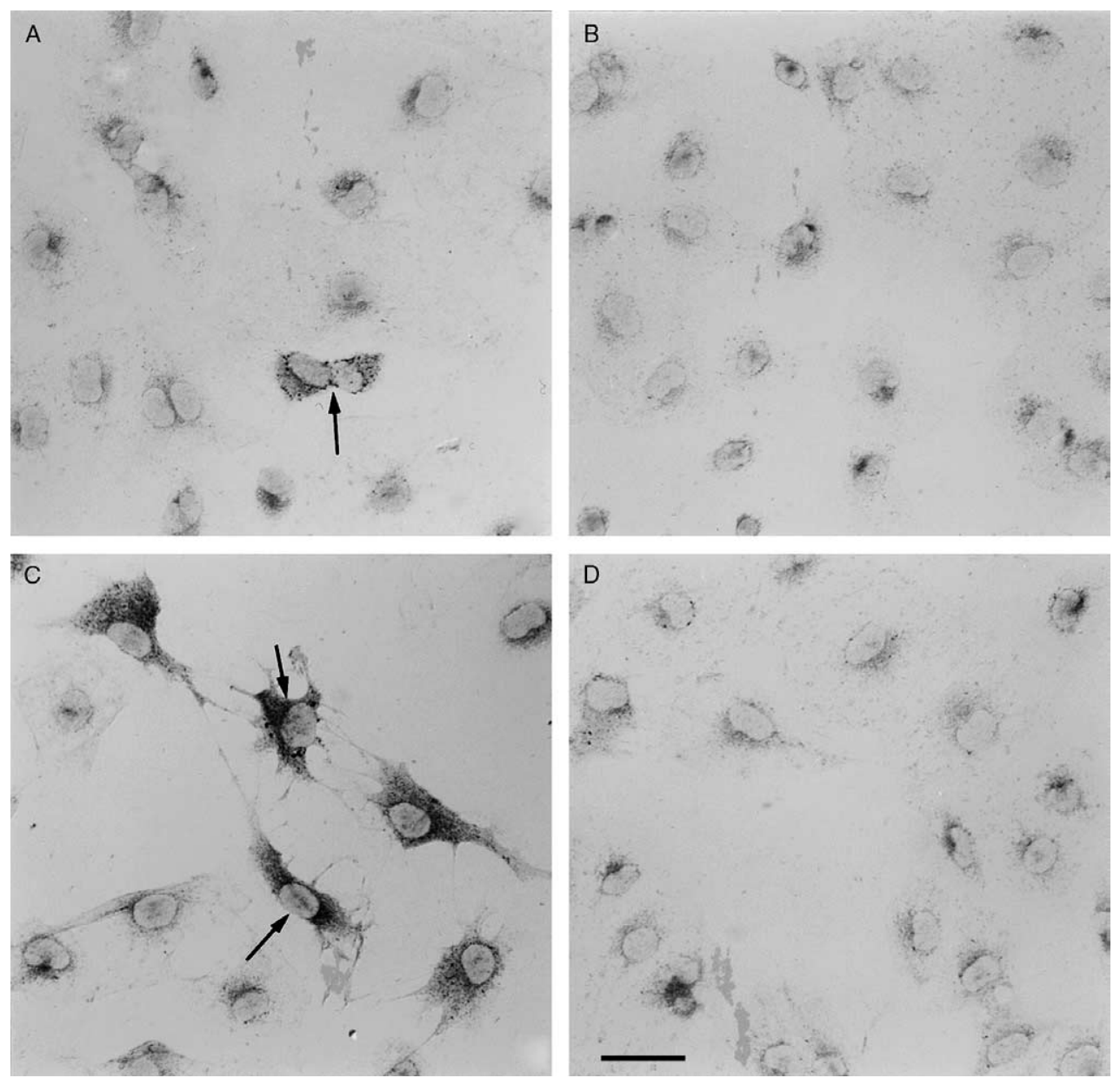

Figure 4 In situ hybridisation of 3 $\beta$-HSD mRNA. Interstitial cells were isolated from 13 -day-old rat testes and cultured for 8 days in the absence ( $A$ and $B$ ) or the presence $(C$ and $D)$ of $10 \mathrm{ng} / \mathrm{ml} \mathrm{LH}$ ( $A$, C anti-sense probe and $B, D$ sense probe). Cells expressing $3 \beta-H S D$ mRNA stained blue, some cells are indicated by arrows.

Original magnification $574 \times$, bar $17 \mathrm{~m}$.

cell proliferation, were added to interstitial cells that were isolated from 13-day-old rat testes and cultured without any additions or in the presence of $10 \mathrm{ng} / \mathrm{ml} \mathrm{LH}$ for either 1,3 or 8 days. Neither after 1 day of culture nor after 3 and 8 days of culture a significant difference in the incorporation of $\left[{ }^{3} \mathrm{H}\right]$ thymidine was observed (day 1: control $69 \pm 22$

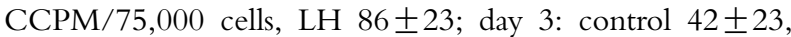

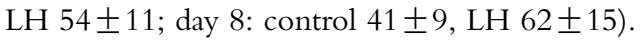

In another experiment, cells were double-labelled with antibodies against BrdU and $3 \beta-\mathrm{HSD}$ to identify Leydig cell progenitors. Neither after 1 day of culture nor after 3 days of culture, the percentage of double-labelled Leydig cell progenitors differed significantly from zero, nor did the percentage of double-labelled cells differ significantly between the control and the LH-treated cultures (day 1: control $0 \cdot 1 \pm 0 \cdot 1 \%$ of cells was double-labelled, LH $0 \cdot 2 \pm$ $0 \cdot 2 \%$; day 3: control $0 \cdot 1 \pm 0 \cdot 1 \%$, LH $0 \cdot 3 \pm 0 \cdot 1 \%)$. The percentage of single-labelled BrdU-positive cells also did not differ significantly between the control and LH-treated cells after 1 and 3 days of culture (day 1: control $3 \cdot 7 \pm 1 \cdot 4 \%$ of cells labelled, LH $3 \cdot 1 \pm 1 \cdot 3 \%$; day 3: control $0 \cdot 2 \pm 0 \cdot 2 \%$, LH $0 \cdot 4 \pm 0 \cdot 1 \%)$. The BrdU labelling experiment was not expanded up to 8 days of culture because by that time the cells had ceased to proliferate (Teerds, unpublished data). Since these observations fitted well with the results of the methylene blue cell viability assay (see above), the $\left[{ }^{3} \mathrm{H}\right]$ thymidine incorporation and double-labelling experiments were not continued in the other treatment groups.

Under none of the culture conditions as described in this study, an effect on the percentage of $3 \beta$-HSD-positive cells was observed following daily addition of $26 \mathrm{M}$ DHT either alone or in combination with LH (data not shown). Precursor cell differentiation was not affected by the addition of oestradiol. Only a dose of $0.5 \mu \mathrm{M}$ oestradiol caused a slight but significant (30\%) inhibition in LH-stimulated progenitor cell formation when cells were isolated from 13-day-old rats 

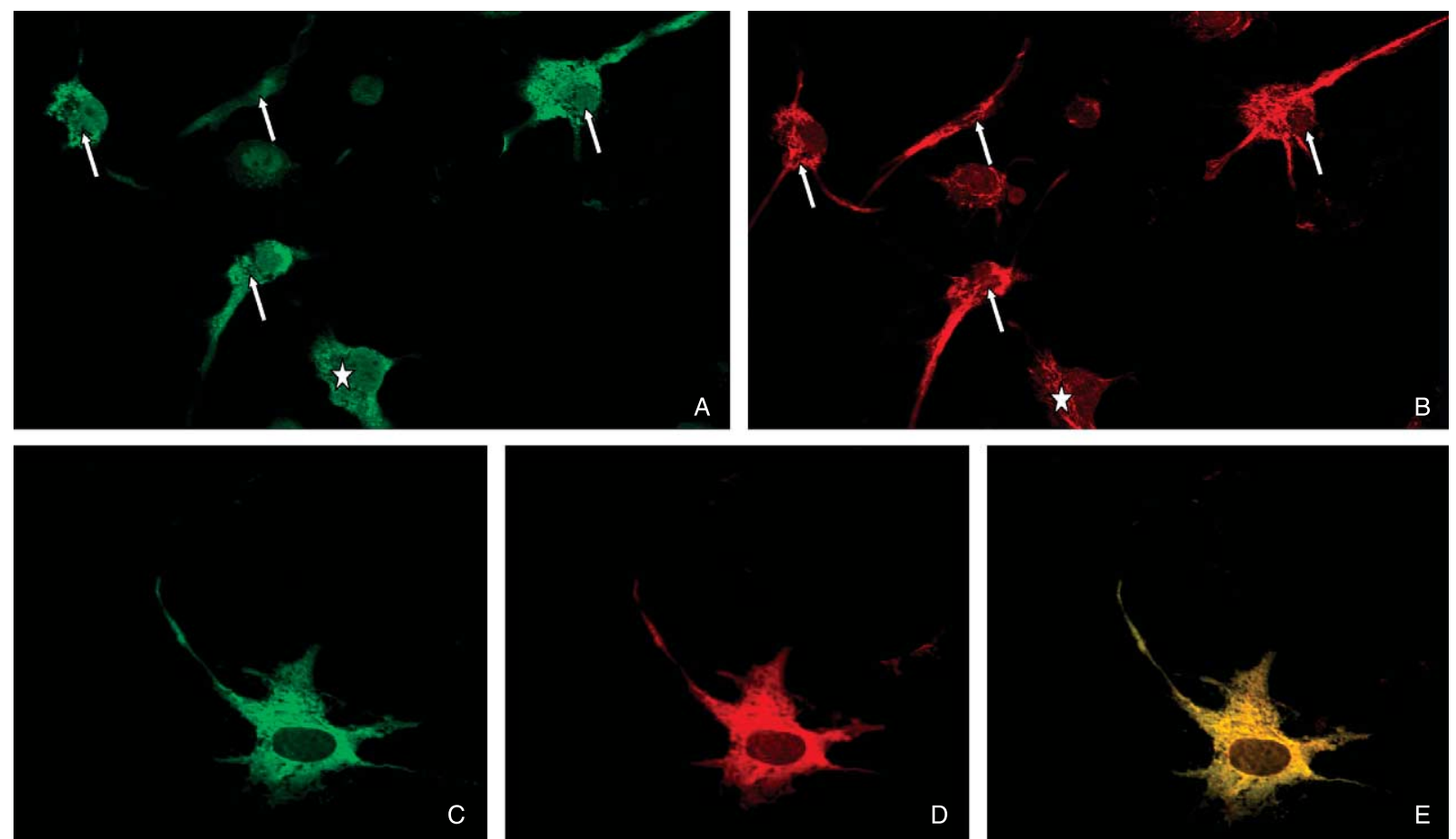

Figure 5 Immunohistochemical double staining for the concomitant detection of LH receptors and $3 \beta$-HSD. Interstitial cells were isolated from 13-day-old rat testes and cultured for 1 day without addition of $\mathrm{LH}$. Following fixation, the cells were double stained with antibodies against the LH receptor and $3 \beta-H S D$. Cells were studied using a Leica confocal laser-scanning microscope. (A and C) Green LH receptorpositive cell(s) visualized using the FITC channel; (B and D) same cell(s) stained for the presence of $3 \beta$-HSD, visualized using the TRITC channel; (E) same cell(s) from C and D now visualized through both the FITC and TRITC channel (yellow fluorescence). In A and B, doublelabelled cells are indicated by arrows, a cell which stained positive only with the LH receptor antibody and in which the $3 \beta$-HSD staining did not reach above the background level is indicated by an asterisk. Original magnification $1732 \times$.

and cultured for 8 days in the presence of $10 \mathrm{ng} / \mathrm{ml} \mathrm{LH}$ $(P<0 \cdot 05)$.

\section{$3 \beta-H S D$ in situ hybridisation}

The detection of LH-induced changes in 3ß-HSD enzyme activity as an index of cell differentiation was validated by comparing the effects of $\mathrm{LH}$ on the number of cells expressing $3 \beta-H S D$ mRNA. Interstitial cells were isolated from testes of 13-day-old rats and cultured without $\mathrm{LH}$ or in the presence of $10 \mathrm{ng} / \mathrm{ml} \mathrm{LH}$. After a culture period of 8 days, the increase in the percentage of $3 \beta-H S D$ mRNA expressing Leydig cell progenitors was similar to that observed after histochemical detection of $3 \beta-H S D$ enzyme activity (Fig. 4). Therefore, the in situ hybridisation experiments for $3 \beta-\mathrm{HSD}$ mRNA expression were not continued for interstitial cells isolated from either 10- or 18-day-old rats, or with other doses of LH.

\section{$3 \beta-H S D$ and LH receptor immunohistochemistry}

The possible co-localisation of $\mathrm{LH}$ receptors and $3 \beta-\mathrm{HSD}$ in mesenchymal-like precursor cells and Leydig cell progenitors was investigated by immunohistochemistry (Fig. 5). Interstitial cells were isolated from 13-day-old rats and cultured without or in the presence of $10 \mathrm{ng} / \mathrm{ml} \mathrm{LH}$ for 1,3 or 8 days. Immunohistochemical detection of these two antigens was determined by fluorescent confocal laser scanning microscopy: the LH receptor was detected using the FITC (green) channel and $3 \beta-H S D$ was detected by using the TRITC (red) channel. In each culture, a minimum of 200 single- and/or double-labelled cells was counted. After 1 day of culture without LH $9 \cdot 5 \pm 3 \cdot 5 \%$ of the fluorescent cells counted stained positively with only the LH receptor antibody, while the percentage of double-labelled cells ( $3 \beta-H S D$ and $\mathrm{LH}$ receptor positive) was $90 \cdot 5 \pm 3 \cdot 5$ (Fig. 5A-C). Cells staining positively for $3 \beta-H S D$ alone were not detected. After culturing the cells for 3 days in the presence of $\mathrm{LH}$, the percentage of single-labelled $\mathrm{LH}$ receptor-positive cells had become significantly lower $(2 \cdot 8 \pm 1 \cdot 6 ; \quad P<0 \cdot 05)$ compared with the controls. Concomitantly, the percentage of double-labelled cells had increased up to $97 \cdot 2 \pm 1 \cdot 6$ in these cultures. After 8 days of culture in both the control and the cultures treated with $\mathrm{LH}$, the percentage of cells that stained positively for the $\mathrm{LH}$ receptor alone had become negligible.

In an additional in vivo experiment, paraffin-embedded sections of testes from 7-, 8-, 10-, 12- or 13-day-old rats were double-labelled with the antibodies against the LH receptor 

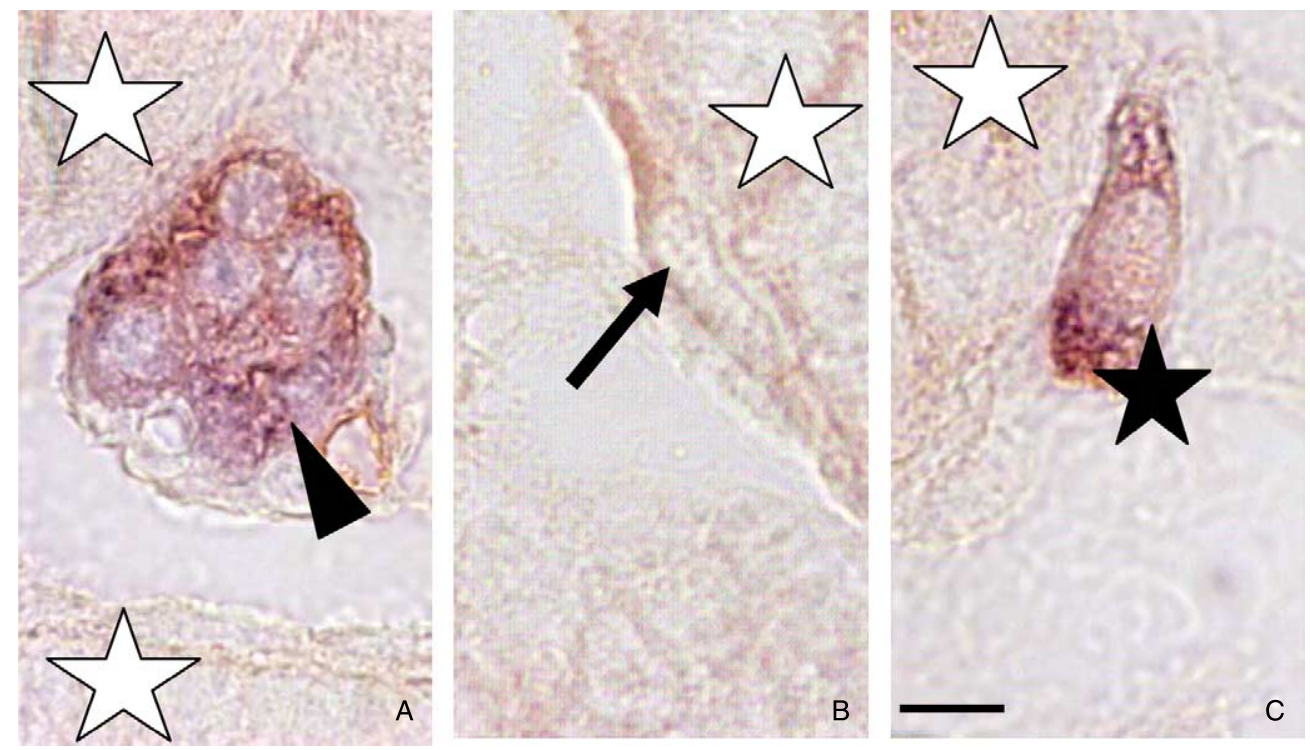

Figure 6 Immunohistochemical double staining for the concomitant detection of LH receptors and 3 $\beta$-HSD in the prepubertal testis. (A) Cluster of double stained ( $\mathrm{LH}$ receptor (brown) and 33-HSD (blue))-positive foetaltype Leydig cells (arrowhead) in the testis of a 7-day-old rat. A seminiferous tubule is indicated by a white asterisk; (B) peritubularly located spindle-shaped precursor cell (black arrow) in the testis of a 12-day-old rat staining positively (brown) with the LH receptor antibody. No $3 \beta-H S D$ staining (blue) could be detected in this cell; (C) peritubularly located double-labelled ( $\mathrm{LH}$ receptor and $3 \beta-\mathrm{HSD}$ positive) oval-shaped Leydig cell progenitor in the testis of a 13-day-old rat. The sections were not counterstained. Original magnification $1435 \times$, bar $=6 \cdot 8 \mu \mathrm{m}$.

and $3 \beta$-HSD. In 7-, 8- and 10-day-old testes foetal-type Leydig cells were the only cell type that stained positively with both antibodies (Fig. 6A). In the testes of 12-day-old rats, spindle-shaped cells were observed that stained positively with the LH receptor antibody, while no $3 \beta-\mathrm{HSD}$ immunoreactivity could be detected in these cells (Fig. 6B). In testes of 13-day-old rats, the first double-labelled spindle- to ovalshaped cells were observed (Fig. 6C). These in vivo data confirm our in vitro observations that precursor cells acquire $\mathrm{LH}$ receptors before they differentiate into progenitor cells.

\section{Discussion}

In the present study, the role of $\mathrm{LH}$ in the formation of $\mathrm{LH}$ receptor/3 $\beta-H S D-p o s i t i v e$ Leydig cell progenitors was investigated in vitro. In order to obtain stem Leydig cells/precursor cells at different stages of the developmental process, interstitial cells were isolated from rats at the ages of 10,13 and 18 days. The presence of $3 \beta-H S D$ enzyme activity and/or the presence of LH receptors were used as differentiation parameters. Cells that expressed only LH receptors were considered to be precursor cells that had developed from stem Leydig cells (Ge et al. 2006), while cells that expressed both LH receptor and $3 \beta-\mathrm{HSD}$ protein were considered to be Leydig cell progenitors. Independent of the age at the time of cell isolation or the duration of the culture period, no cells were observed that stained only positive with the $3 \beta-H S D$ antibody. This was confirmed by an in vivo double-labelling experiment in which in 12-day-old rat testes, single-labelled $\mathrm{LH}$ receptor-positive cells could be observed, but no single-labelled 3 $\beta$-HSD-positive cells were found. When in vitro a dose of $\mathrm{LH}$ as low as $0 \cdot 1 \mathrm{ng} / \mathrm{ml}$ was added to the cultures, the percentage of $3 \beta-H S D-$ positive Leydig cell progenitors increased in nearly all cases significantly. Independent of the age of the animals at the time of interstitial cell isolation, no appreciable cell proliferation could be detected at any time during culturing, indicating that the increase in the percentage of 3 $\beta-H S D-$ positive cells in vitro was most likely the reflection of differentiation of stem Leydig cells/precursor cells rather than division of foetal-type Leydig cells or newly formed Leydig cell progenitors.

The responsiveness of the $\mathrm{LH}$ receptor system was intact in terms of stimulation of cAMP production, even after 15 days of culture. The maximal capacity for the production of cAMP in the presence of $100 \mathrm{ng} / \mathrm{ml} \mathrm{LH}$ was lower in cells that were cultured in the continuous presence of $10 \mathrm{ng} / \mathrm{ml} \mathrm{LH}$. This is very likely a reflection of desensitisation of the $\mathrm{LH}$ receptor system (Hsueh et al. 1977, Nozu et al. 1981, Calvo et al. 1984, LaPolt et al. 1991, Amsterdam et al. 2002).

Our hypothesis that LH is essential for the differentiation of precursor cells into Leydig cell progenitors is based on observations in adult rats. After the destruction of the existing Leydig cell population by the cytotoxic drug ethane dimethyl sulphonate (EDS), regeneration of a new adult-type Leydig 
cell population occurred only in the presence of $\mathrm{LH}$ (Molenaar et al. 1986b, Veldhuizen-Tsoerkan et al. 1994, Teerds 1996, Tena-Sempere et al. 1997, Teerds et al. 1999). This regeneration process shows many similarities with the development of the adult-type Leydig cell population in the (pre)pubertal testis (Teerds 1996). Recently, however, some groups have questioned the role of $\mathrm{LH}$ in the initiation of progenitor Leydig cell development. In LH receptor knockout (LuRKO) mice testes, Zhang et al. $(2001,2002)$ showed by immunohistochemistry that in the absence of $\mathrm{LH}$ receptor signalling at days 10 and 20 after birth a few $\mathrm{P}_{450} 0_{17 \alpha}$ and $3 \beta$ HSD type I positively labelled cells could be detected in close vicinity of the seminiferous tubules. The morphology of these cells resembles the morphology of Leydig cell progenitors as does the location where the labelled cells are found, suggesting that a limited number of progenitors may have develop in the absence of active LH receptor signalling. These authors concluded that $\mathrm{LH}$ receptor signalling is important for Leydig cell differentiation after birth, though the initiation of adult Leydig cell differentiation in the mouse testis can begin independently of LH action. Our present in vitro study expands these observations by showing that it seems to be only a small subpopulation of cells that can initiate differentiation independent of LH signalling. For the majority of the stem Leydig cells/precursor cells, the presence of LH is essential to induce normal differentiation into $3 \beta-H S D-$ positive progenitor cells.

The levels of some steroidogenic enzymes were severely reduced in the adult LuRKO mice testes, while the expression of thrombospondin 2, a marker for foetal-type Leydig cells, was not reduced (Zhang et al. 2001, 2004). The levels $3 \beta$-HSD type VI mRNA expression, a marker for adult-type Leydig cells, were only slightly higher in testes of 60-day-old LuRKO mice compared with 10- and 20-day-old LuRKO and wild-type mice. These observations made the authors conclude that the majority of Leydig cells present in the adult LuRKO mouse testis will be of foetal origin (Zhang et al. 2004). It is not clear from these studies whether the progenitor cells that have developed in the prepubertal LuRKO testis persist during adulthood. Clearly, the nature of the Leydig cells in the adult LuRKO testis needs further investigation.

In another study, Baker et al. (2003) reported that in the testes of adult hpg mice genes were expressed, which are present only in the adult-type Leydig cell lineage, such as $3 \beta$ HSD type VI and $17 \beta-H S D$ type III. The number of Leydig cells present in adult hpg mice was, however, only $10 \%$ of wildtype mice (Baker \& O'Shaughnessy (2001). Although we also found indications that differentiation of some precursor cells into Leydig cell progenitors may have occurred independently from $\mathrm{LH}$, their number was limited. It is, however, questionable whether hpg mice which have a defect in the synthesis of gonadotrophin releasing hormone $(\mathrm{GnRH})$ but which are not a GnRH knockout, completely lack circulating LH. It may depend on the sensitivity of the LH RIA that has been used whether investigators have been able to detect of LH (and follicle-stimulating hormone, FSH) in plasma of hpg mice (van Casteren et al. 2000). Some investigators have reported that LH levels in hpg mice were undetectable (e.g. Baker et al. 2003), while others presumably using a more sensitive RIA showed that LH levels in these mice varied between $<0 \cdot 2$ and $0 \cdot 5 \mathrm{ng} / \mathrm{ml}$ (Gibson et al. 1994, Barkan et al. 2005). The results of the present in vitro study demonstrated that adult-type Leydig cell development can take place in the presence of an amount of LH as low as $0.01 \mathrm{ng} / \mathrm{ml}$, levels that cannot be measured by RIA at present (van Casteren et al. 2000). In vitro conditions are of course not similar to the in vivo situation and, therefore, one has to be cautious when extrapolating in vitro data to the in vivo situation. Nevertheless, the observations of the present study do suggest that the very low levels of circulating LH in hpg mice may possibly be high enough to induce the formation of mature adult-type Leydig cells. This could also explain why Baker et al. (2003) were able to detect specific markers for mature adult-type Leydig cells, such as $17 \beta-\mathrm{HSD}$, in the testes of adult hpg mice, while Zhang and colleagues were unable to detect this enzyme in the adult LuRKO testis. Whether the low levels of LH in hpg mice are indeed of influence on progenitor formation needs to be further investigated by for instance immunising hpg mice from birth to adulthood against $\mathrm{LH}$, thus eliminating the effect of residual LH on this developmental process. It would be of interest to determine what happens to the final number of Leydig cells in the adult hpg testis under these conditions and whether these cells express more adult-type steroidogenic enzymes or more enzymes characteristic for less welldifferentiated Leydig cells such as progenitor cells.

Our hypothesis that $\mathrm{LH}$ is essential for the normal development of Leydig cell progenitors is further confirmed by the immunohistochemical $\mathrm{LH}$ receptor $/ 3 \beta-\mathrm{HSD}$ doublelabelling experiments. We never observed a cell that was solely labelled with the $3 \beta-\mathrm{HSD}$ antibody, neither in vitro nor in vivo. On the other hand, cells that stained positively with only the $\mathrm{LH}$ receptor antibody were detected in vitro regularly. In vivo, these cells were most often observed in a peritubular location in testes of 12-day-old rats, while spindle- to ovalshaped LH receptor and $3 \beta-\mathrm{HSD}$-positive progenitor cells were observed for the fist time in testes of rats at 13 days post partum (pp). These results are in contrast to what has been reported by Ariyaratne et al. (2000), who showed by immunohistochemistry that in vivo Leydig cell progenitors first express $3 \beta-H S D$ as well as other steroidogenic enzymes before the LH receptor becomes detectable. These authors concluded that the development of spindle-shaped precursor cells into progenitor cells took place independently from LH. The discrepancy with the in vitro and in vivo data in the present study cannot be explained by the use of different $\mathrm{LH}$ receptor antibodies, since Ariyaratne et al. (2000) employed the same LH receptor antibody as used in the current experiments. A possible explanation for this contradiction may be that Ariyaratne and colleagues did not use immunohistochemical double labelling to determine the presence of $\mathrm{LH}$ receptors and $3 \beta-$ HSD in the same spindle-shaped cell, but used serial 
sections. Especially, the spindle-shaped precursor cells are relatively small and therefore the amount of cytoplasm present in the sections may have been too limited to be able to detect the LH receptor and $3 \beta-H S D$ antigen in the same cell in serial sections. Furthermore, the techniques used in the present study to detect the two antigens, immunofluorescence and three-step immunohistochemistry (using the Vector Stain kit elite) were more sensitive than the detection method used by Ariyaratna and colleagues.

In order to exclude that the increase in the percentage of Leydig cell progenitors was the result of cell proliferation and not differentiation of precursor cells, we determined the viability of the cells using the methylene blue cell viability assay as well as the incorporation of the proliferation markers $\left[{ }^{3} \mathrm{H}\right]$ thymidine and BrdU. No significant differences in cell viability were observed at any time between the control and the LH-treated cultures. The percentage of 3 $\beta$-HSD-BrdU double-labelled Leydig cell progenitors was negligible under all conditions, suggesting that the increases in the percentages of $3 \beta$-HSD-positive cells was the consequence of differentiation of precursor cells into Leydig cell progenitors and not the result of proliferation of foetal-type Leydig cells and/or newly formed Leydig cell progenitors.

Although the percentage of foetal-type Leydig cells in the cultures was low and these cells did not contribute to the increase in 3 $\beta$-HSD-positive cells after 3 and 8 days of culture as discussed above, it would be appropriate if one could discriminate even after 8 days of culture between foetal-type Leydig cells and newly formed progenitor Leydig cells. As shown in the study by Zhang et al. (2004), there are at present no specific markers available that can discriminate $100 \%$ successfully between these two cell types. This group showed that adult-Leydig cell markers, such as $17 \beta-$ HSD type III are not only expressed by adult Leydig cells and their progenitors, but also by foetal-type Leydig cells. The group of MendisHandagama has suggested that $11 \beta-H S D$ type I may be a marker for progenitor Leydig cells that have developed between days 10 and 13 post partum since this enzyme was detected by immunohistochemistry in these cells, while at the same time, it was not present in foetal-type Leydig cells (Ariyaratne et al. 2000). This study, however, contradicts observations by other groups. Phillips et al. (1989) showed for instance that $11 \beta-H S D$ immunoreactivity could not be detected before the age of 26 days in the rat testis when progenitors have nearly completed their differentiation into immature Leydig cells. The group of Hardy showed that $11 \beta$ HSD type I activity, mRNA and protein levels were very low to nearly absent in highly purified 21-day-old progenitor cells (Ge et al. 1997), confirming the observations by Philips and colleagues.

In several older studies, it has been suggested that foetaltype Leydig cells disappear from the testis relatively rapid after birth. Isolation of foetal Leydig cells among other interstitial cells from testes of 10- or 13-day-old rats could possibly 'rescue' these cells from undergoing degeneration, and these 'rescued' foetal-type Leydig cells could then contribute to the increasing number of $3 \beta-H S D-$ positive cells during culture. We do not think, however, that this likely to occur, since Kerr \& Knell (1988) have shown in an extensive morphometric analysis that the number of foetal-type Leydig cells after birth remains constant up to 2 weeks post partum, followed by a gradual decrease. Between the age of 21 and 100 days, the size of the foetal-type Leydig cell population remains relatively constant at $50-75 \%$ of its original size at the time of birth.

As indicated above, the results of the present study emphasis the importance of LH in the differentiation of precursor cells into Leydig cell progenitors. Nevertheless, under the present culture conditions differentiation of a subpopulation of precursor cells can apparently take place without the immediate presence of $\mathrm{LH}$. Based on the present in vitro data, it is not possible to speculate about the exact size of this subpopulation of cells. Indications that heterogeneity may exist in the Leydig stem cell/precursor cell population also comes from older studies in which adult rats received daily injections of hCG. Within 2 days after the start of treatment the Leydig cell population had increased by $35 \%$ as a result of stem Leydig cell/precursor cell differentiation, Leydig cell proliferation being negligible. These newly formed Leydig cells have characteristics in common with progenitor cells (Teerds et al. 1988, 1992, Teerds 1996). Despite the observed heterogeneity in the adult testis, there are several possible explanations for the autonomous differentiation of this subpopulation of precursor cells into Leydig cell progenitors in the prepubertal testis. First, of all, these cells may have been primed by LH before isolation and no longer depend on the presence of LH in the culture medium. Secondly, the LH receptor on these precursor cells may show intrinsic activation during the first days of culture, making the immediate presence of LH less relevant for the differentiation process (personal communication of Prof. I Huhtaniemi).

When interstitial cells were isolated at the age of 10 days, it took between 3 and 8 days for $\mathrm{LH}$ to induce the formation of

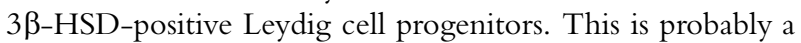
reflection of the fact that the stem Leydig cells/precursor cells at day 10 post partum are less well developed and need more time to differentiate into progenitor cells. This assumption is supported by the observation that a small though not significant increase in the percentage of $3 \beta-H S D$-positive cells in untreated control cultures was observed after 8 days of culture.

After isolation of interstitial cells at day 18 after birth only a marginal increase in the percentage of $3 \beta-H S D$-positive cells was observed after 3 days of culture in the presence of the highest dose of LH. Hardy et al. $(1990,1991)$ did not observe this small increase under their culture conditions, but these investigators used a dose of LH comparable with $0 \cdot 1 \mathrm{ng} / \mathrm{ml}$. We observed that in the presence of such a low dose of $\mathrm{LH}$, it took between 3 and 8 days of culture to induce an increase in the percentage of $3 \beta-H S D$-positive cells. Another difference between the experimental design of the study by Hardy and the present one is that we isolated interstitial cells from 18-day-old animals, while these authors used 21-day-old rats. 
We preferred to use 18-day-old animals since in vivo studies have demonstrated that at this age the wave of Leydig cell progenitor proliferation has not yet been initiated; this starts around the age of 21 days in rats (Hardy et al. 1989).

The present study also investigated the role of steroids in the regulation of Leydig cell development. In contrast to the group of Hardy (Hardy et al. 1990), we were unable to demonstrate a stimulating effect of daily treatment with large amounts of DHT $(26 \mu \mathrm{M})$ on precursor cell differentiation in vitro. We did notice, however, that with increasing age at the time of cell isolation, higher doses of LH and longer culture periods were necessary to induce progenitor formation in vitro. Possibly, the addition of high doses of DHT and thus saturation of the androgen receptor has sensitised precursor cells isolated from 21-day-old rats for $\mathrm{LH}$ to enhance the efficiency of progenitor development, but not in cells isolated from 18-day-old animals. Oestradiol induced a small inhibitory effect on progenitor formation after 8 days of culture. The dose of oestradiol needed was, however, very high in relation to the concentrations present in body fluids under physiological conditions. Hence, non-specific effects of the added oestradiol cannot be excluded. Inhibitory effects of large doses of oestradiol on the development of adult-type Leydig cells have also been observed in vivo in prepubertal rats (Abney 1999) and in adult rats following administration of EDS (Abney \& Myers 1991). Again, it cannot be excluded that this inhibition is caused by non-specific effects of the very high doses of oestradiol used in these studies.

Taken together, the regulation of the development of the adult-type Leydig cell population, as discussed above, is a complicated process. A summary is given in Fig. 7. In brief, spindle-shaped stem Leydig cells undergo proliferation and differentiation under the influence of the growth factors like LIF, SCF, PDFG-A and EGF/TGF- $\alpha$, and the thyroid hormone triiodothyronine $\left(T_{3}\right)$. This initial phase of differentiation does take place independent of LH (Ge et al. 2006). In the strain of rats used in the present study, the stem Leydig cells differentiate between days 10 and 12 after birth into spindle-shaped precursor cells which express LH receptors. Under the influence of LH, DHT (Hardy et al. 1990) and $T_{3}$, these cells develop, around the age of 13 days, into $3 \beta-H S D-p o s i t i v e$ progenitor cells that have an elongated to oval shape and contain lipid droplets in their cytoplasm (Haider 2004, Ge et al. 2006). In the absence of LH or LH receptor signalling, formation of progenitor cells is severely inhibited, although a small subpopulation of cells can differentiate into progenitor cells without the immediate presence of LH (Zhang et al. 2004, the present study). Besides LH, the expression of Dhh (Clark et al. 2000) and the presence of macrophages (Gaytan et al. 1994) in the testis also appears to be important for this phase of the developmental process. Increased oestradiol levels inhibit the formation of progenitors at least in part (Abney 1999). The newly formed Leydig cell progenitors undergo several waves of proliferation (Hardy et al. 1989) under the influence of LH and local produced growth factors (for review see Haider 2004). In contrast to mature Leydig cells, the major steroids produced by progenitor cells are $5 \alpha$-reduced androgens such as DHT (O'Shaughnessy et al. 2002, Haider 2004, Ge et al. 2005). Between days 28 and 35 after birth, the progenitors differentiate into immature polygonal-shaped Leydig cells that have still some lipid droplets in their cytoplasm; when these cells undergo further differentiation proliferation ceases and $5 \alpha$-reductase levels decrease. At the same time, the levels

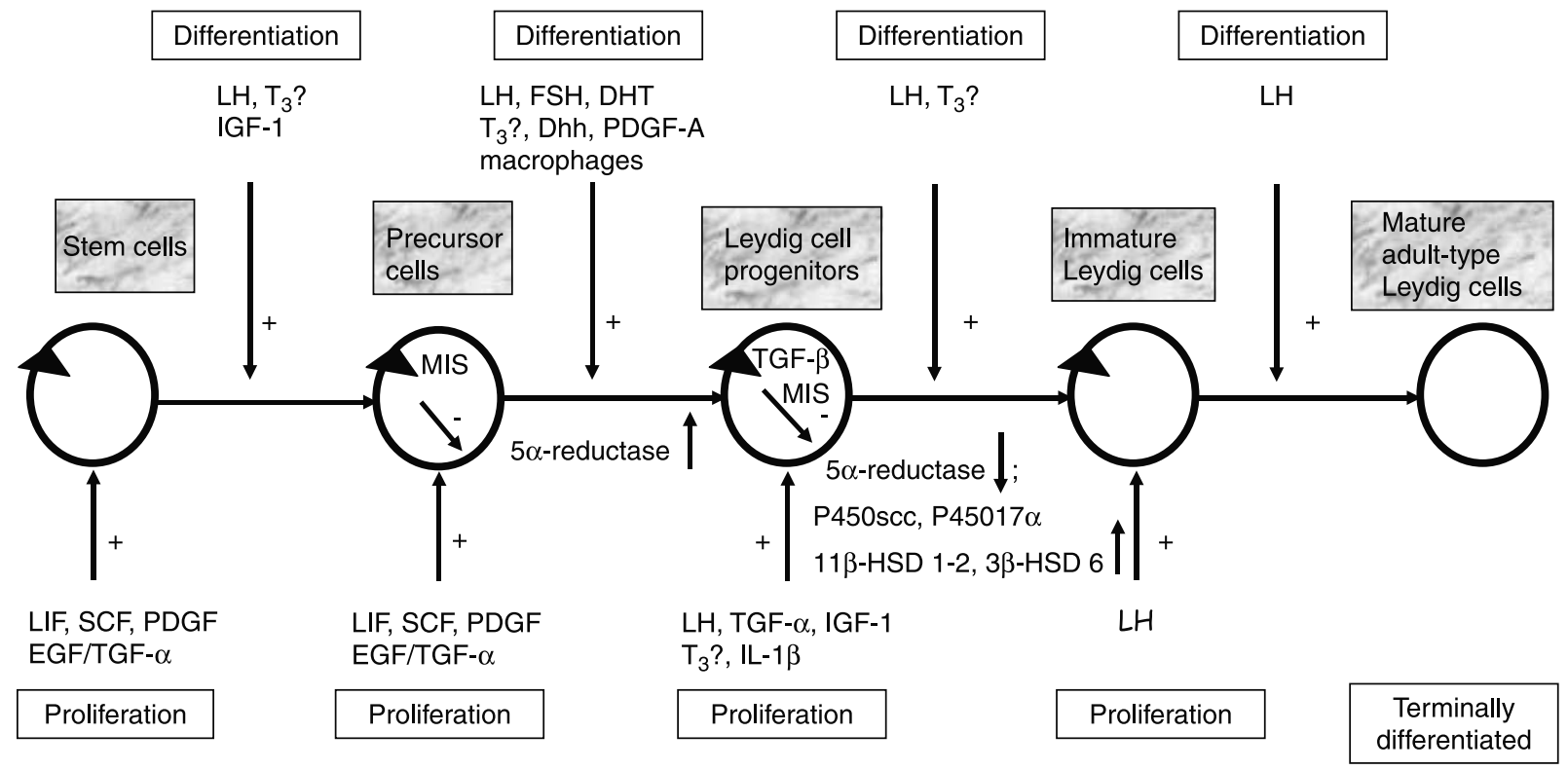

Figure 7 Integrated model for the development of adult-type Leydig cells in the (pre)pubertal testis. The model is explained in the Discussion section. 
of other steroidogenic enzymes, such as $\mathrm{P} 450_{\mathrm{scc}}, \mathrm{P} 450_{17 \alpha}$, $11 \beta$-HSD type 1 and 2 , as well as $3 \beta$-HSD type VI begin to increase (Wiebe 1976, Ge \& Hardy 1998, O'Shaughnessy et al. 2000, 2002, Zhang et al. 2004, Ge et al. 2005). Around the age of 60 days, most immature Leydig cells have under the influence of LH and possibly other (growth) factors developed into terminally differentiated mature adult-type Leydig cells with a characteristic large round shape (Haider 2004). In conclusion, even though certain phases of the developmental process may take place in the absence of LH or LH signalling, it is clear that for the development of a normal sized adulttype Leydig cell population, LH is indispensable.

\section{Acknowledgements}

The authors thank Dr J C Stoof (Free University, Amsterdam, The Netherlands) for the cAMP antibody, Dr J Wimalasema (University of Tennessee, Knoxville, TN, USA) for the LH receptor antibody and Dr I Mason (University of Edinburgh, Edinburgh, Scotland) for the $3 \beta$-HSD probe and Dr A H Payne (Stanford University School of Medicine, Stanford, CA, USA) for the $3 \beta-H S D$ antibody. We are grateful to Dr I Schipper (Erasmus University, Rotterdam, The Netherlands) for his help with the cAMP assay and to Mr H Halsema (Utrecht University, Utrecht, The Netherlands) for preparing the figures. The authors declare that there is no conflict of interest that would prejudice the impartiality of this scientific work.

\section{Funding}

This work was supported in part by a senior fellowship of the Royal Netherlands Academy of Arts and Sciences to K J T.

\section{References}

Abney TO 1999 The potential roles of estrogens in regulating Leydig cell development and function: a review. Steroids 64 610-617.

Abney TO \& Myers RB 199117 beta-estradiol inhibition of Leydig cell regeneration in the ethane dimethylsulfonate-treated mature rat. Journal of Andrology 12 295-304.

Ahmad N, Haltmeyer GC \& Eik-Nes KB 1973 Maintenance of spermatogenesis in rats with intratesticular implants containing testosterone or dihydrotestosterone (DHT). Biology of Reproduction 8 411-419.

Amsterdam A, Hanoch T, Dantes A, Tajima K, Strauss JF \& Seger R 2002 Mechanisms of gonadotrophin desensitization. Molecular and Cellular Endocrinology 187 69-74.

Ariyaratne HBS, Mendis-Handagama SMLC, Hales DB \& Mason JI 2000 Studies on the onset of Leydig precursor cell differentiation in the prepubertal rat testis. Biology of Reproduction 63 165-171.

Baker PJ \& O'Shaughnessy PJ 2001 Role of gonadotrophins in regulating numbers of Leydig and Sertoli cells during fetal and postnatal development in mice. Reproduction 122 227-234.

Baker PJ, Johnston H, Abel M, Charlton HM \& O’Shaughnessy PJ 2003 Differentiation of adult-type Leydig cells occurs in gonadotrophin-deficient mice. Reproductive Biology and Endocrinology 14.

Barkan D, Hurgin V, Dekel N, Amsterdam A \& Rubenstein M 2005 Leptin induces ovulation in GnRH-deficient mice. FASEB Journal 19 133-135.
Calvo JC, Radicella JP, Pignataro OP \& Charreau EH 1984 Effect of a second injection of human chorionic gonadotrophin on the desensitized Leydig cells. Molecular and Cellular Endocrinology 34 31-38.

van Casteren JI, Schoonen WG \& Kloosterboer HJ 2000 Development of time-resolved immunofluorometric assays for rat follicle-stimulating hormone and luteinizing hormone and application on sera of cycling rats. Biology of Reproduction 62 886-894.

Chemes HE, Gottlieb SE, Pasqualini T, Domenichini E, Rivarola MA \& Bergada C 1985 Response to acute hCG stimulation and steroidogenic potential of Leydig cell fibroblastic precursors in humans. Journal of Andrology 6 102-112.

Clark AM, Garland KK \& Russell LD 2000 Desert hedgehog (Dhh) gene is required in the mouse testis for formation of adult-type Leydig cells and normal development of peritubular cells and seminiferous tubules. Biology of Reproduction 63 1825-1838.

Gaytan F, Bellido C, Aguilar E \& van Rooijen N 1994 Requirement for testicular macrophages in Leydig cell proliferation and differentiation during prepubertal development in rats. Journal of Reproduction and Fertility 102 393-399.

Ge RS \& Hardy MP 1998 Variation in the end products of androgen biosynthesis and metabolism during postanatal differentiation of rat Leydig cells. Endocrinology 139 3787-3795.

Ge RS, Hardy DO, Catterall JF \& Hardy MP 1997 Developmental changes in glucocorticoid receptor and $11 \beta$-hydroxysteroid dehydrogenase oxidative and reductive activities in rat Leydig cells. Endocrinology 138 5089-5095.

Ge RS, Dong Q, Sottas CM, Chen H, Zirkin BR \& Hardy MP 2005 Gene expression in rat Leydig cells during development from the progenitor to adult stage: a cluster analysis. Biology of Reproduction 72 1405-1415.

Ge RS, Dong Q, Sottas CM, Papadopoulos V, Zirkin BR \& Hardy MP 2006 In search of rat stem Leydig cells: Identification, isoaltion, and lineagespecific development. PNAS 103 2719-2724.

Gibson MJ, Kasowski H \& Dobrjansky A 1994 Continuous gonadotrophinreleasing hormone infusion stimulates dramatic gonadal development in hypogonadal female mice. Biology of Reproduction 50 680-685.

Gnessi L, Basciani S, Mariani S, Arizzi M, Spera G, Wang C, Bondjers C, Karlsson L \& Betsholtz C 2000 Leydig cell loss and spermatogenic arrest in platelet-derived growth factor (PDGF)-A-deficient mice. Journal of Cell Biology 149 1019-1026.

Goldman R \& Bar-Shavit Z 1979 Dual effect of normal and stimulated macrophages and their conditioned media on target cell proliferation. Journal of the National Cancer Institute 63 1009-1016.

Haider SG 2004 Cell biology of Leydig cells in the testis. International Review of Cytology 233 181-241.

Hardy MP, Zirkin BR \& Ewing LL 1989 Kinetic studies on the development of the adult population of Leydig cells in testes of the pubertal rat. Endocrinology 124 762-770.

Hardy MP, Kelce WR, Klinefelter GR \& Ewing LL 1990 Differentiation of Leydig cell precursors in vitro: a role for androgen. Endocrinology 127 488-490.

Hardy MP, Gelber SJ, Zhou ZF, Penning TM, Ricigliano JW, Ganjam VK, Nonneman D \& Ewing LL 1991 Hormonal control of Leydig cell differentiation. Annals of the New York Academy of Sciences 637 152-163.

Harper JF \& Brooker G 1975 Femtomole sensitive radioimmunoassay for cyclic AMP and cyclic GMP after 2' 0 acetylation by acetic anhydride in aqueous solution. Journal of Cyclic Nucleotide Research $1207-218$.

Hsueh AJ, Dufau ML \& Catt KJ 1977 Gonadotrophin-induced regulation of luteinizing hormone receptors and desensitization of testicular $3^{\prime}: 5^{\prime}$-cyclic AMP and testosterone responses. PNAS 74 592-595.

Kerr JB \& Knell CM 1988 The fate of fetal Leydig cells during the development of the fetal and postnatal rat testis. Development 103 535-544.

Ketelslegers JM, Hetzel WD, Sherins RJ \& Catt KJ 1978 Developmental changes in testicular gonadotrophin receptors: plasma gonadotrophins and plasma testosterone in the rat. Endocrinology 103 212-222.

De Kretser DM \& Kerr JB 1994 The cytology of the testis. In The Physiology of Reproduction, pp 1177-1290. Eds E Knobil \& JD Neill. New York: Raven Press. 
LaPolt PS, Jia XC, Sincich C \& Hsueh AJ 1991 Ligand-induced downregulation of testicular and ovarian luteinizing hormone $(\mathrm{LH})$ receptors is preceded by tissue-specific inhibition of alternatively processed $\mathrm{LH}$ receptor transcripts. Molecular Endocrinology 5 397-403.

Lojda Z, Gossrau R \& Schreiber TH 1979 Enzyme Histochemistry. A Laboratory Manua., New York: Springer Verlag.

Lording DW \& de Kretser DM 1972 Comparative ultrastructural and histochemical studies of the interstitial cells of the rat testis during fetal and postnatal development. Journal of Reproduction and Fertility 29 261-269.

Majdic G, Saunders PT \& Teerds KJ 1998 Immunoexpression of the steroidogenic enzymes 3-beta hydroxysteroid dehydrogenase and 17 alphahydroxylase, C17,20 lyase and the receptor for luteinizing hormone (LH) in the fetal rat testis suggests that the onset of Leydig cell steroid production is independent of LH action. Biology of Reproduction 58 520-525.

Mendis-Handagama SM \& Ariyaratne HB 2001 Differentiation of the adult Leydig cell population in the postnatal testis. Biology of Reproduction 65 660-671.

Mendis-Handagama SM, Risbridger GP \& de Kretser DM 1987 Morphometric analysis of the components of the neonatal and the adult rat testis interstitium. International Journal of Andrology 10 525-534.

Molenaar R, Rommerts FF \& van der Molen HJ 1986a Non-specific esterase: a specific and useful marker enzyme for Leydig cells from mature rats. Journal of Endocrinology 108 329-334.

Molenaar R, de Rooij DG, Rommerts FF \& van der Molen HJ $1986 b$ Repopulation of Leydig cells in mature rats after selective destruction of the existent Leydig cells with ethylene dimethane sulfonate is dependent on luteinizing hormone and not follicle-stimulating hormone. Endocrinology 118 2546-2554.

Nozu K, Matsuura S, Catt KJ \& Dufau ML 1981 Modulation of Leydig cell androgen biosynthesis and cytochrome P-450 levels during estrogen treatment and human chorionic gonadotrophin-induced desensitization. Journal of Biological Chemistry 256 10012-10017.

O'Shaughnessy PJ, Baker PJ, Heikkila M, Vainio S \& McMahon AP 2000 Localization of 17beta-hydroxysteroid dehydrogenase/17-ketosteroid reductase isoform expression in the developing mouse testis-androstenedione is the major androgen secreted by fetal/neonatal leydig cells. Endocrinology 141 2631-2637.

O'Shaughnessy PJ, Willerton L \& Baker PJ 2002 Changes in Leydig cell gene expression during development in the. Biology of Reproduction 66 966-975.

Phillips DM, Lakshmi V \& Monder C 1989 Corticosteroid $11 \beta$ dehydrogenase in rat testis. Endocrinology 125 209-216.

Schipper I, Fauser BC, ten Hacken PM \& Rommerts FF 1996 Application of a CHO cell line transfected with the human FSH receptor for the measurement of specific FSH receptor activation inhibitors in human serum. Journal of Endocrinology 150 505-514.

Sharpe RM 1987 Testosterone and spermatogenesis. Journal of Endocrinology $1131-2$.

Slegtenhorst-Eegdeman KE, de Rooij DG, Verhoef-Post M, van de Kant HJG, Bakker CE, Oostra BA, Grootegoed A \& Themmen APN 1998 Macroorchidism in FMR1 knockout mice is caused by increased Sertoli cell proliferation during testicular development. Endocrinology 139 156-162.
Teerds KJ 1996 Regeneration of Leydig cells after EDS - a model for postnatal Leydig cell renewal. In The Leydig cell, pp 203-220. Eds LD Russell, AH Payne \& MP Hardy. Vienna, IL: Cache River Press.

Teerds KJ \& Dorrington JH 1993 Immunohistochemical localization of $3 \beta-$ hydroxysteroid dehydrogenase in the rat ovary during follicular development and atresia. Biology of Reproduction 49 989-996.

Teerds KJ, de Rooij DG, Rommerts FFG \& Wensing CJG 1988 The regulation of the proliferation and differentiation of rat Leydig cell precursors after EDS administration or daily hCG treatment. Journal of Andrology 9 343-351.

Teerds KJ, Closset J, Rommerts FF, de Rooij DG, Stocco DM, Colenbrander B, Wensing CJ \& Hennen G 1989 Effects of pure FSH and LH preparations on the number and function of Leydig cells in immature hypophysectomized rats. Journal of Endocrinology 120 97-106.

Teerds KJ, de Rooij DG, Wensing CJG \& Rommerts FFG 1992 Hormoneinduced resistance of rat Leydig cells to the cytotoxic effects of ethane-1,2dimethane sulphonate. Journal of Endocrinology 134 85-90.

Teerds KJ, de Boer-Brouwer M, Dorrington JH, Balvers M \& Ivell R 1999 Identification of markers for precursor and Leydig cell differentiation in the adult rat testis following ethane dimethyl sulphonate administration. Biology of Reproduction 60 1437-1445.

Tena-Sempere M, Rannikko A, Kero J, Zhang FP \& Huhtaniemi IT 1997 Molecular mechanisms of reappearance of luteinizing hormone receptor expression and function in rat testis after selective Leydig cell destruction by ethylene dimethane sulfonate. Endocrinology 138 3340-3348.

Veldhuizen-Tsoerkan MB, Ivell R \& Teerds KJ 1994 hCG-induced changes in LH/CG receptor mRNA transcript levels in the testis of adult hypophysectomized, ethane dimethyl sulphonate-treated rats. Molecular and Cellular Endocrinology 105 37-44.

Vergouwen RP, Jacobs SG, Huiskamp R, Davids JA \& de Rooij DG 1991 Proliferative activity of gonocytes, Sertoli cells and interstitial cells during testicular development in mice. Journal of Reproduction and Fertility 93 233-243.

Wiebe JP 1976 Steroidogensis in rat Leydig cells: changes in activity of 5-ane and 3 -ene-3 $\beta$ hydroxysteroid dehydrogenase during sexual maturation. Endocrinology 98 505-513.

Zhang FP, Poutanen M, Wilbertz J \& Huhtaniemi I 2001 Normal prenatal but arrested postnatal sexual development of luteinizing hormone receptor knockout (LuRKO) mice. Molecular Endocrinology 15 172-183.

Zhang FP, Poutanen M \& Huhtaniemi I 2002 Gene modified animal models for the study of luteinizing hormone and luteinizing hormone receptor function. In Testicular Tangrams, pp 85-97. Eds FFG Rommerts \& KJ Teerds. Berlin: Ernst Springer Research Foundation Workshop.

Zhang FP, Pakarainen T, Zhu F, Poutanen M \& Huhtaniemi I 2004 Molecular characterization of postnatal development of testicular steroidogenesis in luteinizing hormone receptor knockout mice. Endocrinology 145 1453-1463.

Received in final form 26 June 2007

Accepted 27 June 2007

Made available online as an Accepted Preprint 28 June 2007 